\begin{tabular}{|c|c|c|}
\hline $\begin{array}{l}\text { OPEN ACCESS } \\
\text { Vol.4 No.1: 12-19 } \\
\text { Tahun 2020 } \\
\text { Artikel penelitian 貳 }\end{array}$ & $\begin{array}{l}\text { Jurreal Alewatiklestari } \\
\text { E-ISSN: 2598-8204 } \\
\text { http://ojs.umrah.ac.id/index.php/akuatiklestari } \\
\text { DOI: https://doi.org/10.31629/akuatiklestari.v4i1.2458 }\end{array}$ & $Q_{2}=$ \\
\hline
\end{tabular}

\title{
Pola Sebaran dan Kepadatan Cerithiidae di Ekosistem Mangrove dan Padang Lamun di Perairan Pulau Penyengat Kecamatan Tanjungpinang Kota
}

\author{
The distribution and Density of Cerithiidae in Mangrove and area Seagrass Ecosystems in Penyengat \\ Island Waters, Tanjungpinang City District.
}

Putra Sanjaya1, Febrianti Lestari1 ${ }^{\bowtie}$, Susiana $^{1}$

1Manajemen Sumberdaya Perairan, Fakultas Ilmu Kelautan dan Perikanan, Universitas Maritim Raja Ali Haji, Tanjungpinang, Indonesia 29111

$\square$ Info Artikel:

Diterima: 16 Agustus 2020

Revisi: 28 September 2020

Disetujui: 8 Oktober 2020

Dipublikasi: 30 November 2020

\section{[a] Keyword:}

Cerithiidae, Kepadatan, Pola sebaran,

Pulau Penyengat

\section{$\triangle$ Penulis Korespondensi:}

Febrianti Lestari

Manajemen Sumberdaya Perairan,

Fakultas IImu Kelautan dan Perikanan,

Universitas Maritim Raja Ali Haji,

Tanjungpinang, Indonesia 29111

Email: febi_estary@umrah.ac.id

\begin{abstract}
ABSTRAK. Tujuan penelitian ini untuk mengetahui pola sebaran dan kepadatan Cerithiidae pada ekosistem Mangrove dan padang lamun di perairan Pulau Penyengat. Penentuan stasiun penelitian menggunakan metode purposive sampling sebanyak 2 stasiun yaitu stasiun I kawasan ekosistem mangrove dan padang lamun, yang ada aktivitas masyarakat dan stasiun II kawasan ekosistem mangrove dan padang lamun tidak ada aktivitas masyarakat. Pengambilan sampel Cerithiidae dilakukan sebanyak 12 kali ulangan pada setiap stasiun, menggunakan transek $1 \times 1$ meter. Pola sebaran stasiun I dan II kawasan ekosistem padang lamun memiliki nilai yang cenderung sama dengan nilai Id (indek morisita) 8,19 dan Id 9,78 dikategorikan mengelompok. Sama halnya stasiun I dan II kawasan mangrove dengan nilai Id 2,29 dan Id 2,42 juga dikategorikan mengelompok. Sedangkan tingkat kepadatan stasiun I dan II ekosistem padang lamun memiliki kepadatan yang cendrung sama dengan nilai yaitu stasiun I, $25.555 \mathrm{ind} / \mathrm{Ha}$ dan stasiun II, $24.722 \mathrm{ind} / \mathrm{Ha}$, sama halnya tingkat kepadatan stasiun I dan II kawasan mangrove tidak berbeda dengan nilai rata-rata tingkat kepadatan stasiun I yaitu 20.873 ind/Ha dan stasiun II 17.963 ind/Ha. Selanjutnya hasil analysis principal component analysis (PCA) dengan karakteristik penciri lingkungan pada stasiun I ekosistem mangrove yaitu $\mathrm{pH}$ tidak memiliki keterkaitan dengan tingkat kepadatan Cerithiidae. Selanjutnya Pada stasiun I ekosistem padang lamun terdiri dari Salanitas, suhu, dan DO memiliki keterkaitan terhadap tingkat kepadatan. Pada stasiun II ekosistem mangrove dengan karakteristik penciri lingkungan yaitu TOM tidak memiliki keterkaitan terhadap tingkat kepadatan. Selanjutnya pada stasiun II ekosistem padang lamun dengan karakteristik penciri lingkungan yaitu Kecepatan arus dan Substrat juga tidak memiliki keterkaitan dengan tingkat kepadatan Cerithiidae.
\end{abstract}

ABSTRACT. The purpose of this study was to determine the distribution pattern and the density of Cerithiidae in the mangrove ecosystem and seagrass beds in the waters of Penyengat Island. Determination of research stations used 2 purposive sampling methods, there were 2 stations namely Station I area of mangrove ecosystem and seagrass area, which has community activities and Station II area of mangrove ecosystem and seagrass area there is no community activity. Cerithiidae sampling was carried out 12 replications at each station, using a $1 \times 1$ meter transect. The distribution of station I and II in the seagrass area has a value that tends to be the same as the value of Id (morisita index) 8.19 and Id 9.78 is categorized as a group. Both of, stations I and II stations of the mangrove area with a value of Id 2.29 and Id 2.42 were also categorized as clusters. Whereas the density of station I and II of seagrass has a density that tends to be the same as the value of station I, 25,555 ind / Ha and station II, 24,722 ind / Ha, similarly the density level of station I and II of mangrove area is not diverse from the average value the average density of station I is 20,873 ind / Ha and station II 17,963 ind / Ha. Furthermore, the results of principal component analysis (PCA) analysis with environmental characteristics at station I of the mangrove ecosystem, namely $\mathrm{pH}$ has no relationship with the density level of Cerithiidae. Furthermore, at station I, the seagrass beds consist of salinity, temperature, and DO which are related to the level of density. At station II the mangrove ecosystem with environmental characteristics, namely TOM, has no relationship to density levels. Furthermore, at station II seagrass beds with environmental characteristics, namely current velocity and substrate, also have no relationship with the density level of Cerithiidae.

望 How to cite this article:

Sanjaya, P., Lestari, F., \& Susiana. (2020). Pola Sebaran dan Kepadatan Cerithiidae di Ekosistem Mangrove dan Padang Lamun di Perairan Pulau Penyengat Kecamatan Tanjungpinang Kota. Jurnal Akuatiklestari, 4(1): 12-19. DOI: https://doi.org/10.31629/akuatiklestari.v4i1.2458 


\section{PENDAHULUAN}

Pulau Penyengat terletak di Kelurahan Penyengat, Kecamatan Tanjungpinang Kota, Kota Tanjungpinang, Provinsi Kepulauan Riau. Sebagai wilayah pesisir Pulau Penyengat mempunyai keanekaragaman hayati yang cukup tinggi seperti ekosistem Lamun, mangrove, terumbu karang, ikan, dan berbagai jenis moluska. Hal tersebut mengakibatkan tingginya potensi kawasan pesisir baik dari segi ekologi dan ekonomi. Selanjutnya gastropoda mempunyai peranan penting dalam ekosistem, terlibat dalam siklus rantai makanan, yaitu sebagai sumber makanan bagi hewan-hewan lainya. salah satu jenis makrozoobenthos penghuni kawasan pesisir adalah Cerithiidae. Cerithiidae merupakan famili dari filum molusca yang memiliki ukuran kecil dan hidup di wilayah pesisir. Famili Cerithiidae merupakan keluarga dengan distribusi tinggi dan komponen biotik penting dalam struktur komunitas (Gohel et al., 2016) Makrozoobentos jenis ini adalah kelompok herbivora dengan jenis makanan berupa alga dan detritus pada permukaan substrat. Sebagai pemakan detritus dan alga, Cerithiidae sangat berkontribusi terhadap daur ulang karbon serta transfer dari produksi primer bentik ke tingkat tropik yang lebih tinggi (Houbrick, 1985). Menurut Saputri (2019), Cerithiidae memiliki peran penting bagi lingkungan yaitu untuk mestabilkan bahan organik yang ada di perairan dan juga sebagai penanda suatu lingkungan perairan tersebut memiliki bahan organik tinggi. Salah satu famili Cerithiidae yaitu Clypeomorus coralium, merupakan jenis asli penghuni hutan mangrove dan memiliki toleransi yang tinggi terhadap perubahan kondisi lingkungan (Rangan, 2010), ada juga yang melimpah pada substrat berpasir yaitu jenis dari Clypeomorus bifasciata (Ira et al., 2015).

Berdasarkan penelitian sebelumnya di perairan Pulau Penyengat yang dilakukan Rosdatina et al. (2019), makrozoobentos yang di jumpai di perairan Pulau Penyengat sebanyak 14 spesies. Dari 14 spesies makrozoobentos yang ditemukan, salah satunya dari famili Cerithiidae. Hasil penelusuran, Pulau Penyengat belum mempunyai data secara ilmiah tentang Cerithiidae. Maka dari itu, pentingnya dilakukan penelitian tentang pola sebaran dan kepadatan Cerithiidae di perairan Pulau Penyengat, dikarenakan peneliti ingin mengetahui pola sebaran dan tingkat kepadatan Cerithiidae di perairan Pulau Penyengat Kecamatan Tanjung Pinang Kota. Tujuan penelitian mengetahui pola sebaran Cerithiidae di ekosistem mangrove dan padang lamun di perairan Pulau Penyengat, mengetahui jenis-jenis dan tingkat kepadatan Cerithiidae di ekosistem mangrove dan padang lamun di perairan Pulau Penyengat, serta mengetahui keterkaitan Cerithiidae dengan parameter lingkungan.

\section{BAHAN DAN METODE}

\subsection{Waktu dan Tempat}

Penelitian ini dilaksanakan pada bulan September sampai dengan Desember tahun 2019. Lokasi penelitian dilakukan di kawasan ekosistem mangrove dan padang lamun perairan Pulau Penyengat. Lokasi penelitian dapat dilihat pada Gambar 1.

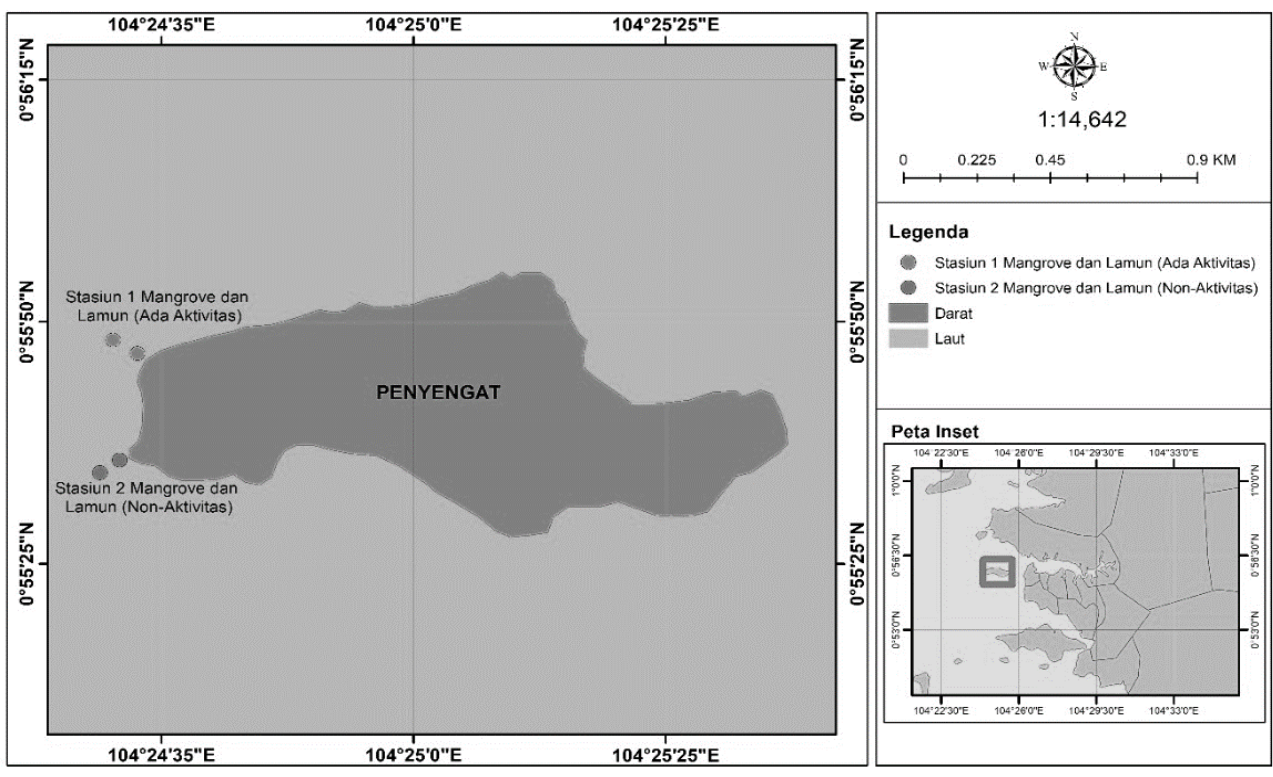

Gambar 1. Peta Lokasi Penelitian Pulau Penyengat

\subsection{Alat dan Bahan}

Adapun peralatan dan bahan yang digunakan dalam penelitian meliputi Transek lxl m, tali, botol, stopwatch, cool box, alat tulis, GPS(Global positioning system), kamera, multitester, mikroskop stereo, handrefraktometer, kantong plastik, skop kecil. Bahan yang digunakan dalam penelitian meliputi aquades, tisu, alkohol $70 \%$.

\subsection{Prosedur Penelitian}

Pengambilan sampel Cerithiidae menggunakan metode Purposive sampling yaitu pengambilan sampel Cerithiidae berdasarkan perbedaan ekosistem pesisir (Mangrove dan Lamun), yang terdapat di perairan Pulau Penyengat. Teknik 
pengambilan sampel Cerithiidae di ekosistem mangrove dan padang lamun menggunakan metode Line Transek yang mengacu pada Fachrul (2007). 1 stasiun memiliki 3 tegakan garis dengan panjang tegakan dibuat $15 \mathrm{~m}$ mengarah ke laut, kemudian antar plot diberi jarak 5 meter. Posisi transek sampling berada di dekat pesisir, tengah dan mengarah kearah laut. Ukuran transek yang digunakan pada mangrove dan padang lamun berukuran lxl $\mathrm{m}$ dan peletakan transek mengacu pada Fachrul (2007). Skema pengambilan sampel dapat dilihat pada Gambar 2.
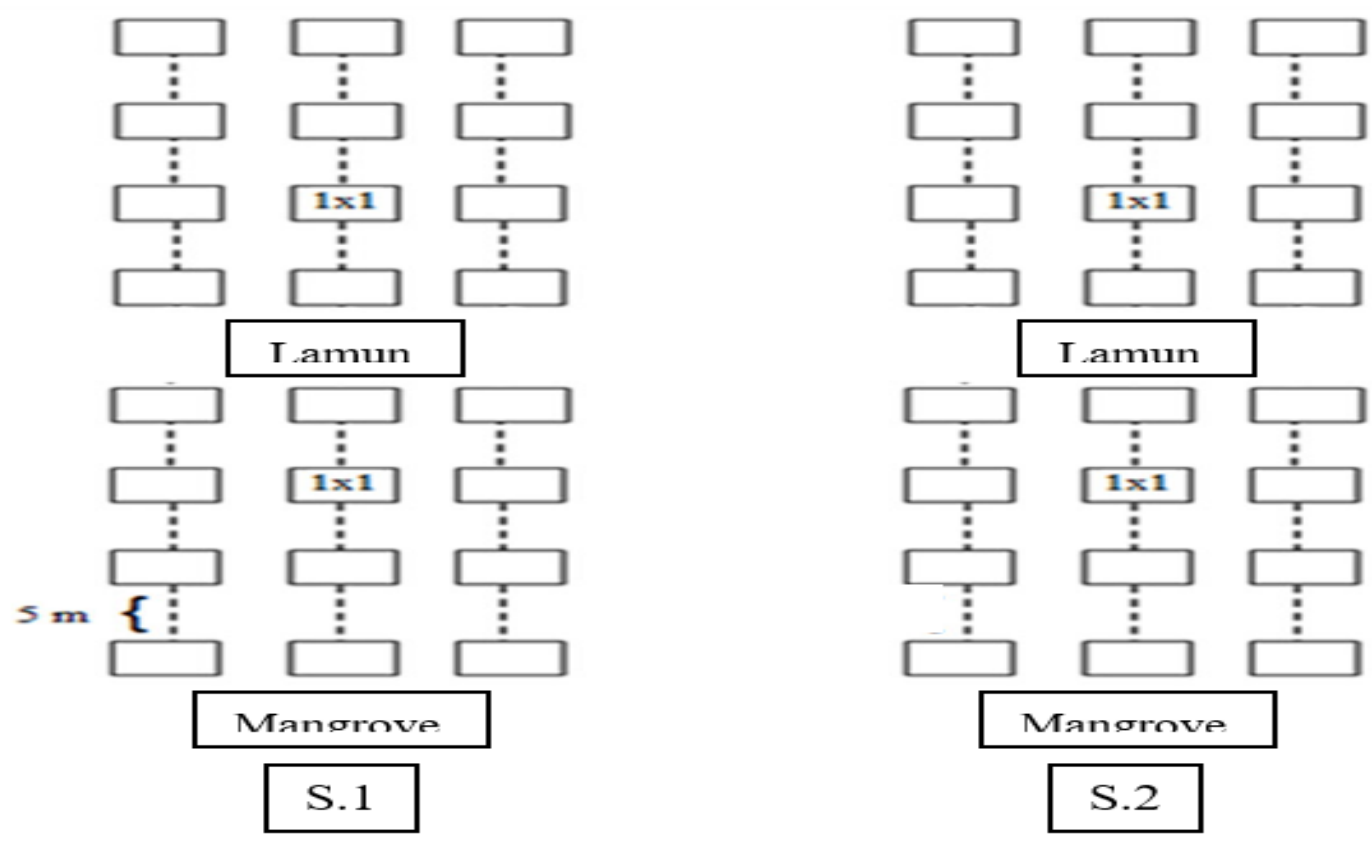

Gambar 2. Line Transek dan Peletakan Plot Pengamatan

Lokasi Sampling Penelitian Berdasarkan Karakteristik

1. Stasiun I : Merupakan ekosistem mangrove dan padang lamun, ada aktivitas masyarakat. lokasi ekosistem mangrove tidak jauh dari pembuangan sampah, kawasan padang lamun lokasi yang sering terlihat masyarakat berkarang.

2. Stasiun II : Merupakan kawasan mangrove dan padang lamun, tidak ada aktivitas masyarakat.

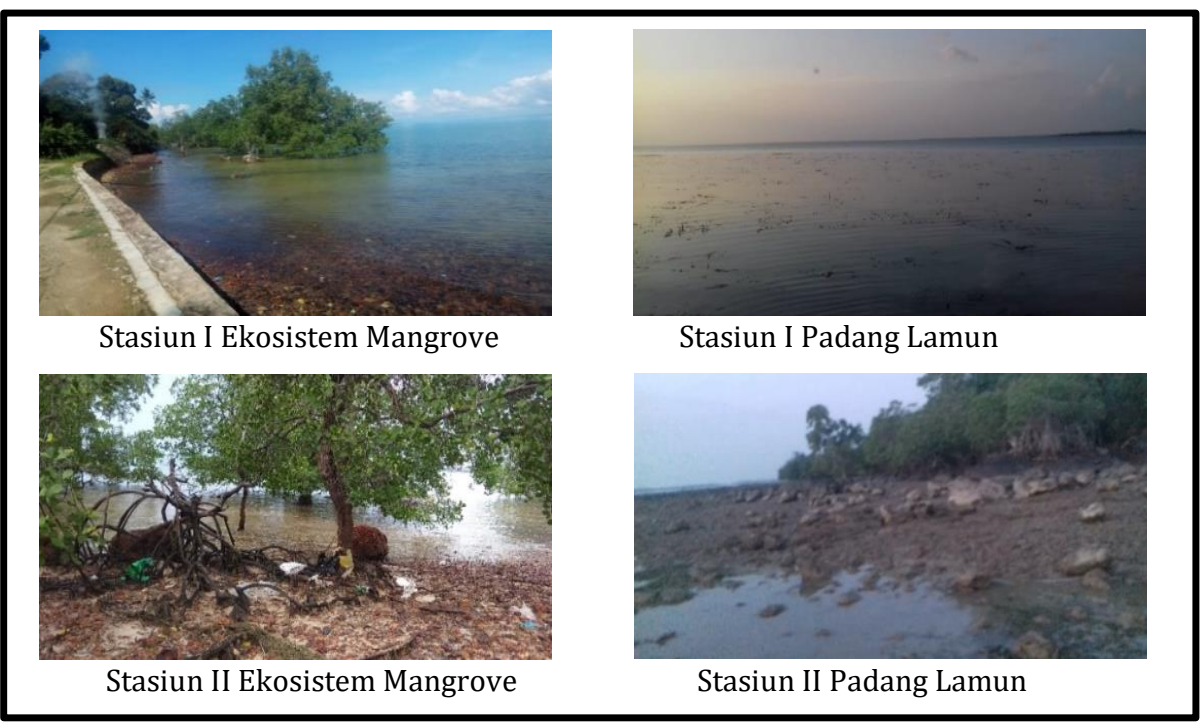

Gambar 3. Lokasi sampling

\subsection{Analisis Data}

\subsubsection{Pola Sebaran}

Pola sebaran Cerithiidae ditentukan dengan menghitung Indeks Dispersi Morisita dengan persamaan yang dikutip dari Krebs (1972) dalam Akhrianti et al. (2014), dengan persamaan:

$$
I d=\frac{n\left(\Sigma X i^{2}-N\right)}{N(N-1)}
$$




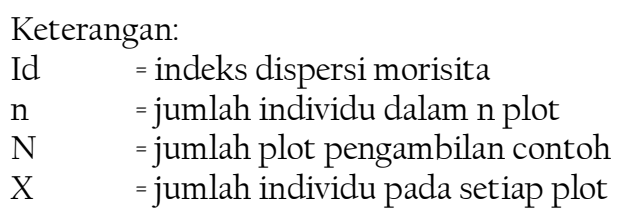

Nilai indeks morisita yang diperoleh diinterpretasikan disajikan pada Tabel 1.

Tabel 1. Kategori Indeks Morisita

\begin{tabular}{ccc} 
No & Indeks Morisita & Kategori \\
1 & $\mathrm{Id}=0$ & Berseragam \\
2 & $\mathrm{Id}<1$ & Acak \\
3 & $\mathrm{Id}>1$ & Berkelompok \\
\hline
\end{tabular}

\title{
2.4.2. Tingkat Kepadatan
}

Kepadatan jenis (a) adalah jumlah individu per satuan luas. Kepadatan Cerithiidae pada setiap stasiun dihitung dan dikonversikan dalam satuan ind/ $\mathrm{m}^{2}$ dengan menggunakan persamaan Ode (2017).

$$
D=\frac{n i}{A} \times 10.000
$$

\author{
Keterangan: \\ $\mathrm{D} \quad=$ jumlah individu persatuan luas (ind $/ \mathrm{Ha}$ ) \\ ni $\quad=$ jumlah individu dalam titik sampling \\ A $\quad=$ luas titik sampling $\left(\mathrm{m}^{2}\right)$ \\ $10000=$ konversi $\mathrm{m}^{2} \mathrm{ke} \mathrm{Ha}$
}

\subsubsection{Karakteristik Penciri}

Karakter penciri Cerithiidae di analisis menggunakan analisis Principle Component Analysis yang mana analisis ini menggunkan software Minitab 16. Principle Component Analysis merupakan analisis penciri karakteristik. Menurut Delsen et al. (2017), Principle Component Analysis adalah salah satu fitur ekstraksi (reduksi) variabel yang banyak digunakan.

\section{HASIL DAN PEMBAHASAN}

\subsection{Pola Sebaran Cerithiidae}

Pola penyebaran spesies di dalam suatu populasi dapat dibedakan menjadi tiga kategori yaitu acak, seragam, dan mengelompok. Hasil perhitungan indeks Morisita pada penelitian ini dapat dilihat pada Tabel 2.

Tabel 2. Pola Sebaran Cerithiidae di Perairan Pulau Penyengat

\begin{tabular}{ccc} 
Stasiun & Id & Pola Sebaran \\
ST I M & 8,19 & Mengelompok \\
ST I L & 2,29 & Mengelompok \\
ST II M & 9,78 & Mengelompok \\
ST II L & 2,42 & Mengelompok \\
\hline
\end{tabular}

Hasil pengukuran pola sebaran Cerithiidae pada seluruh titik sampling di perairan Pulau Penyengat ditemukan pola sebaran mengelompok. Hasil sebaran Cerithiidae pada stasiun I dan II kawasan mangrove yang ada aktivitas dan tidak ada aktivitas cendrung sama dengan nilai Id 8,19 dan Id 9,78 yang dikategorikan mengelompok. Sama halnya pada Stasiun I dan II ekosistem padang lamun dengan nilai Id 2,29 dan 2,42 Id juga dikategorikan mengelompok. Menurut Putra et al. (2018), menyatakan bahwa persebaran populasi organisme di alam umumnya mempunyai persebaran yang mengelompok dan sangat jarang sekali ditemukan dalam pola seragam (merata). Selanjutnya, semakin banyak individu yang memijah maka semakin sering ditemukan pola sebaran yang mengelompok. Lebih lanjut Ode (2017), juga berpendapat pola distribusi mengelompok disebabkan oleh sifat spesies yang bergerombol atau adanya kesamaan habitat sehingga terjadi pengelompokan di tempat lain yang terdapat banyak bahan makanan. Pola sebaran mengelompok berkaitan dengan kondisi lingkungan abiotik (suhu dan salinitas) yang berfluktuasi, ketersediaan bahan organik yang tinggi, tipe substrat yang baik dan cocok bagi kehidupan spesies (Yuniarti, 2012). Hal inilah yang mempengaruhi penyebaran mengelompok pada setiap stasiun penelitian mengelompok. 


\subsection{Tingkat Kepadatan Cerithiidae}

Berdasarkan hasil penelitian yang dilakukan pada perairan Pulau Penyengat teridentifikasi sebanyak 6 jenis Cerithiidae yang tersebar pada 48 transek. Jenis - jenis yang selalu ditemukan pada setiap stasiun yaitu jenis Jenis yang selalu dominan pada setiap stasiun adalah jenis Cerithium zonatum, Cerithium coralium, Cerithium crassilabrum, Clypeomarus batillariaeformis, Clypeomorus concisu dan Bittium glareosum. Adapun kepadatan jenis Cerithiidae yang ditemukan dapat di lihat pada Tabel 3.

Tabel 3. Kepadatan Cerithiidae di Perairan Pulau Penyengat

\begin{tabular}{llllll} 
No. & \multicolumn{1}{c}{ Jenis } & \multicolumn{4}{c}{ Kepadatan Rata-rata (ind/Ha) } \\
& & Stasiun I Aktivitas & Stasiun II Non Aktivitas \\
Lamun & Mangrove & Lamun & Mangrove \\
1 & Cerithium zonatum & 38.333 & & 30.833 & \\
2 & Cerithium coralium & & 57.500 & & 97.778 \\
3 & Clypeomarus batillariaeformis & 43.333 & & 46.667 & \\
4 & Cerithium crassilabrum & 28.333 & & 13.333 & \\
5 & Bittium glaresum & 23.333 & & 35.833 & \\
6 & Clypeomorus concisu & 20.000 & 15.556 & 21.667 & 10.000 \\
\hline \multicolumn{7}{c}{ Kepadatan Rata-Rata } & $\mathbf{2 5 . 5 5 5}$ & $\mathbf{2 0 . 8 7 3}$ & $\mathbf{2 4 . 7 2 2}$ & $\mathbf{1 7 . 9 6 3}$ \\
\hline
\end{tabular}

Hasil rata-rata tingkat kepadatan Cerithiidae di Stasiun I dan II ekosistem padang lamun yang ada aktivitas dan tidak ada aktivitas masyarakat memiliki tingkat kepadatan yang tidak jauh berbeda Stasiun I yaitu 25.555 ind/Ha dan stasiun II $24.722 \mathrm{ind} / \mathrm{Ha}$. Menurut Minarni et al. (2016), mengatakan komunitas gastropoda merupakan komponen yang penting dalam rantai makanan di padang lamun, dimana gastropoda merupakan hewan dasar pemakan detristus (detritus feeder) dan serasah dari lamun yang jatuh dan mensirkulasi zat-zat yang tersuspensi di dalam air guna mendapatkan makanan. Sama halnya Stasiun I dan II kawasan mangrove yang ada aktivitas dan tidak ada aktivitas juga tidak jauh berbeda dengan nilai rata-rata Stasiun I yaitu 20.873 ind/Ha dan stasiun II 17.963 ind/Ha. Nilai rata-rata yang cenderung sama pada tingkat kepadatan Cerithiidae pada stasiun I dan II kawasan mangrove dan lamun, dikarenakan pengaruh parameter lingkungan di perairan Pulau Penyengat memiliki nilai rata-rata cenderung sama. Menurut Supratman et al. (2018), faktor lingkungan seperti cahaya, kecerahan, kekeruhan, suhu, salinitas, dan $\mathrm{pH}$ juga ikut mempengaruhi perkembangbiakannya. Selain faktor lingkungan faktor sampah anorganik juga mempengaruhi keberadaan gastropoda, yang mana pada stasiun I dan II ekosistem mangrove terdapat sampah anorganik. Menurut Djohar et al. (2020), semakin meningkatnya jumlah sampah maka semakin rendah kelimpahan gastropoda.

\subsection{Kualitas Perairan}

Hasil rata-rata pengukuran dapat dilihat pada Tabel 4. Dalam pengukuran kualitas air, parameter fisika dan kimia yang diukur adalah suhu, DO, pH, salinitas, kecepatan arus, TOM, dan tipe substrat. Baku mutu menurut Keputusan Menteri Negara Lingkungan Hidup No 51 tahun 2004 untuk kehidupan organisme akuatik.

Tabel 4. Nilai Beberapa Parameter Fisika dan Kimia Perairan

\begin{tabular}{lcccccc} 
Parameter & Satuan & \multicolumn{2}{c}{ Stasiun } & Baku \\
Fisika & & Lamun & Mangrove & Lamun & Mangrove & \\
\hline Suhu & ${ }^{\circ} \mathrm{C}$ & $30,60 \pm 0,100$ & $30,23 \pm 0,153$ & $30,53 \pm 0,115$ & $30,30 \pm 0,00$ & $28-32$ \\
Kec. Arus & $\mathrm{m} / \mathrm{s}$ & $0,03 \pm 0,007$ & $0,02 \pm 0,002$ & $0,04 \pm 0,003$ & $0,03 \pm 0,003$ & - \\
Substrat & - & Pasir & Pasir & Pasir & Pasir & - \\
\hline Kimia & \multicolumn{7}{c}{ berkerikil } & berkerikil & berkerikil & berkerikil & \\
\hline DO & $\mathrm{mg} / \mathrm{L}$ & $7,43 \pm 0,058$ & $7,30 \pm 0,000$ & $7,37 \pm 0,058$ & $7,33 \pm 0,058$ & $>5$ \\
pH & - & $7,63 \pm 0,058$ & $7,67 \pm 0,058$ & $7,60 \pm 0,00$ & $7,63 \pm 0,058$ & $7-8,5$ \\
Salinitas & $\%$ & $32,33 \pm 0,577$ & $31,67 \pm 0,577$ & $32,00 \pm 0,00$ & $31,67 \pm 0,577$ & Alami \\
TOM & $\%$ & $11,26 \pm 1,043$ & $9,57 \pm 1,937$ & $11,24 \pm 2,802$ & $10,45 \pm 1,087$ & - \\
\hline
\end{tabular}

Ket: *Baku mutu Kepmen LH No 51 tahun 2004

Berdasarkan hasil pengukuran rata-rata nilai suhu pada stasiun I dan II ekosistem padang lamun yang ada aktivitas dan tidak ada aktivitas, dengan nilai yaitu berkisar antara $30,60 \pm 0,100^{\circ} \mathrm{C}$ sampai dengan $30,53 \pm 0,115^{\circ} \mathrm{C}$, dan stasiun I dan II ekosistem mangrove yang ada aktivitas dan tidak ada aktivitas, dengan nilai yaitu berkisar antara $30,23 \pm 0,153^{\circ} \mathrm{C}$ sampai dengan $30,30 \pm 0,000^{\circ} \mathrm{C}$. Menurut Wahyuni et al. (2014), umumnya pada setiap stasiun memiliki suhu yang sama, suhu 
merupakan salah satu faktor yang mempengaruhi distribusi suatu organisme. Menurut Ridwan et al. (2016), mengatakan nilai kisaran suhu $29-35,3^{\circ} \mathrm{C}$ merupakan suhu yang layak untuk mendukung kehidupan organisme bentos dalam ekosistem dimana mereka hidup. Jadi, kisaran suhu perairan yang di dapat pada Stasiun I dan II ekosistem mangrove dan ekosistem padang lamun masih sesuai untuk kehidupan Gastropoda seperti Cerithiidae.

Berdasarkan hasil pengukuran, rata-rata nilai oksigen terlarut Stasiun I dan II ekosistem padang lamun dan ekosistem

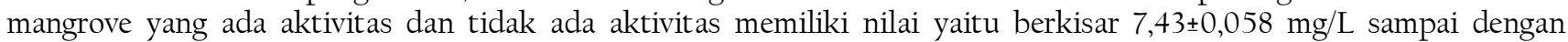
$7,37 \pm 0,058 \mathrm{mg} / \mathrm{L}$ sama halnya pada satsiun I dan II ekosistem mangrove yang ada aktivitas dan tidak ada aktivitas memiliki

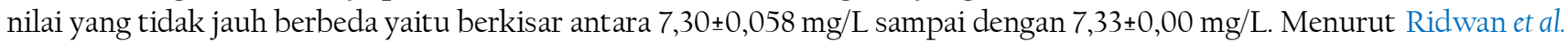
(2016), kandungan oksigen mempengaruhi jumlah jenis organisme di perairan. Jadi nilai oksigen terlarut di perairan Pulau Penyengat cenderung sama. Hal ini sesuai dengan jumlah jenis Cerithiidae yang didapat di perairan Pulau Penyengat memiliki jumlah jenis yang tidak jauh berbeda pada setiap stasiun.

Berdasarkan hasil pengukuran rata-rata nilai $\mathrm{pH}$ Stasiun I dan II ekosistem padang lamun dan ekosistem mangrove

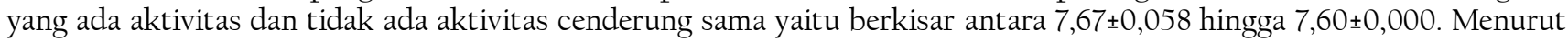
Effendi (2003), sebagian besar biota akuatik sensitif terhadap perubahan $\mathrm{pH}$ dan menyukai nilai pH sekitar 7-8,5. Sehingga nilai pH stasiun I dan II ekosistem mangrove dan padang lamun masih mendukung untuk kehidupan Cerithiidae dan biota lainya.

Berdasarkan hasil pengukuran, rata-rata nilai salinitas Stasiun I dan II ekosistem padang lamun yang ada aktivitas dan tidak ada aktivitas memiliki nilai yang tidak jauh berbeda yaitu berkisar antara 32,33 $\pm 0,577 \%$ sampai dengan $32,00 \pm 0,000 \%$. Stasiun I dan II ekosistem padang lamun yang ada aktivitas dan tidak ada aktivitas memiliki nilai yang

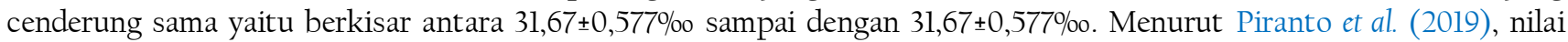
salinitas yang sama di sebabkan pada setiap stasiun terkena pasang surut dalam waktu yang sama. Selanjutnya Riniatsih \& Edi (2009), mengatakan bahwa gastropoda dapat hidup pada kadar salinitas antara 29-32\%o. Nilai salinitas yang di peroleh pada setiap stasiunnya yaitu 32-31\%o, nilai yang didapat masih mendukung kehidupan Cerithiidae di perairan Pulau Penyengat.

Berdasarkan hasil pengukuran, rata-rata nilai kecepatan arus pada stasiun I ekosistem padang lamun berkisar antara $0,03 \pm 0,007 \mathrm{~m} /$ det sampai dengan $0,04 \pm 0,003 \mathrm{~m} / \mathrm{s}$. sedangkan stasiun I dan II kawasan mangrove yaitu berkisar 0,02 $\pm 0,002$ sampai dengan 0,03 $\pm 0,003 \mathrm{~m} / \mathrm{s}$. Menurut Mason (1981) dalam Ira et al. (2015), kecepatan arus perairan dikelompokkan perairan berarus sangat cepat $(>1 \mathrm{~m} / \mathrm{s})$, cepat $(0,5-1 \mathrm{~m} / \mathrm{s})$, sedang $(0,25-0,5 \mathrm{~m} / \mathrm{s})$, lambat $(0,1-0,2 \mathrm{~m} / \mathrm{s})$ dan sangat lambat $(<0,1 \mathrm{~m} / \mathrm{s})$. Maka dari itu kecepatan arus perairan Pulau Penyengat tergolong cepat.

Rata-rata kandungan bahan organik substrat pada Stasiun I dan II ekosistem padang lamun yang ada aktivitas dan tidak ada aktivitas memiliki nilai yang hampir tidak jauh berbeda yaitu berkisar antara 11,26 $\pm 1,043 \%$ sampai dengan

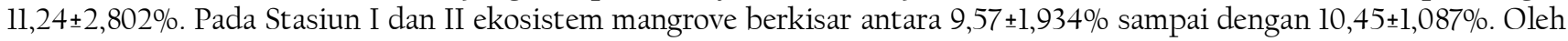
karena itu, kandungan bahan organik di perairan Pulau Penyengat dalam kriteria sedang. Menurut Reynolds (1971) dalam Budiasih et al. (2015), kriteria bahan organik sedimen adalah sangat tinggi : >35, tinggi : 17-35, sedang : 7-17, rendah : 3,5-7, sangat rendah $<3,5$.

Berdasarkan identifikasi substrat di perairan Pulau Penyengat pada Stasiun I dan II memiliki tekstur yang sama yaitu pasir berkerikil. Menurut Sianu et al. (2014) dan Normalasari et al. (2019), Organisme hewan makrobentos umumnya dijumpai pada pantai berpasir karena tipe substrat berpasir akan memudahkan moluska untuk mendapatkan suplai nutrisi dalam air yang diperlukan untuk kelangsungan hidupnya. Selanjutnya Lindawaty et al. (2016) dan Hatijah et al. (2019), juga berpendapat Jenis substrat sangat mempengaruhi penyebaran untuk biota akuatik, substrat pasir dan lumpur cenderung memudahkan biota untuk bergerak dari satu tempat ketempat yang lain.

\subsection{Karakteristik penciri kepadatan dengan parameter lingkungan}

Karakteristik penciri dianalisis dengan menggunakan Analisis Principal Component Analysis, bertujuan untuk melihat keterkaitan kepadatan Cerithiidae dengan parameter lingkungan, disajikan pada Gambar 4. Berdasarkan hasil Principal Component Analysis, karakteristik penciri menunjukan adanya keterkaitan hubungan antara parameter lingkungan stasiun pengamatan. Berdasarkan hasil analisis terbentuk 4 kelompok yaitu kelompok pertama, kelompok kedua, kelompok ketiga dan kelompok keempat. Kelompok pertama yaitu Stasiun I ekosistem mangrove dengan karakteristik penciri lingkungan yaitu pH. pH di stasiun ini tidak memiliki keterkaitan dengan kepadatan. Selanjutnya kelompok kedua yaitu Stasiun I ekosistem padang lamun dengan karakteristik penciri lingkungan yaitu kepadatan, Suhu, DO dan salinitas. Suhu, DO dan salinitas adalah parameter yang memiliki keterkaitan dengan kepadatan di Stasiun I ekosistem padang lamun. Berdasarkan hasil pengamatan bahwa kepadatan Cerithiidae paling banyak di Stasiun I ekosistem padang lamun dengan kepadatan yaitu $25.555 \mathrm{ind} / \mathrm{Ha}$. Selanjutnya kelompok ketiga yaitu Stasiun II ekosistem mangrove dengan karakteristik penciri lingkungan yaitu TOM (total organic metter), TOM di stasiun ini tidak memiliki keterkaitan dengan kepadatan. Selanjutnya kelompok keempat yaitu Stasiun II ekosistem padang lamun dengan karakteristik penciri lingkungan yaitu kecepatan arus dan substrat, kecepatan arus dan substrat di stasiun ini tidak memiliki keterkaitan dengan kepadatan.

Berdasarkan hasil Principal Component Analysis, kelompok pertama Stasiun I ekosistem mangrove dicirikan oleh pH. Menurut Odum (1996), menyatakan bahwa $\mathrm{pH}$ merupakan faktor pembatas bagi organisme dalam suatu perairan dengan pH yang terlalu tinggi atau rendah, akan mempengaruhi ketahanan hidup organisme yang hidup dalam perairan. Pada kelompok kedua Stasiun I ekosistem padang lamun dicirikan oleh kepadatan, salanitas, DO dan suhu, menandakan bahwa kepadatan, salanitas, DO dan Suhu memiliki keterkaitan yaitu suhu adalah salah satu faktor abiotik yang sangat menentukan kelangsungan hidup organisme perairan. Kepadatan Cerithiidae melimpah pada Stasiun I ekosistem padang 
lamun menandakan kondisi lingkungan yang cocok untuk kehidupan Cerithiidae. Menurut Hutagalung (1988), kematian massal organisme biasanya terjadi bila suhu air laut lebih tinggi dari ambang batas atas atau lebih rendah dari ambang batas bawah. Hal itu mengindikasikan bahwa suhu yang terukur di Stasiun I ekosistem padang lamun merupakan suhu yang optimal.

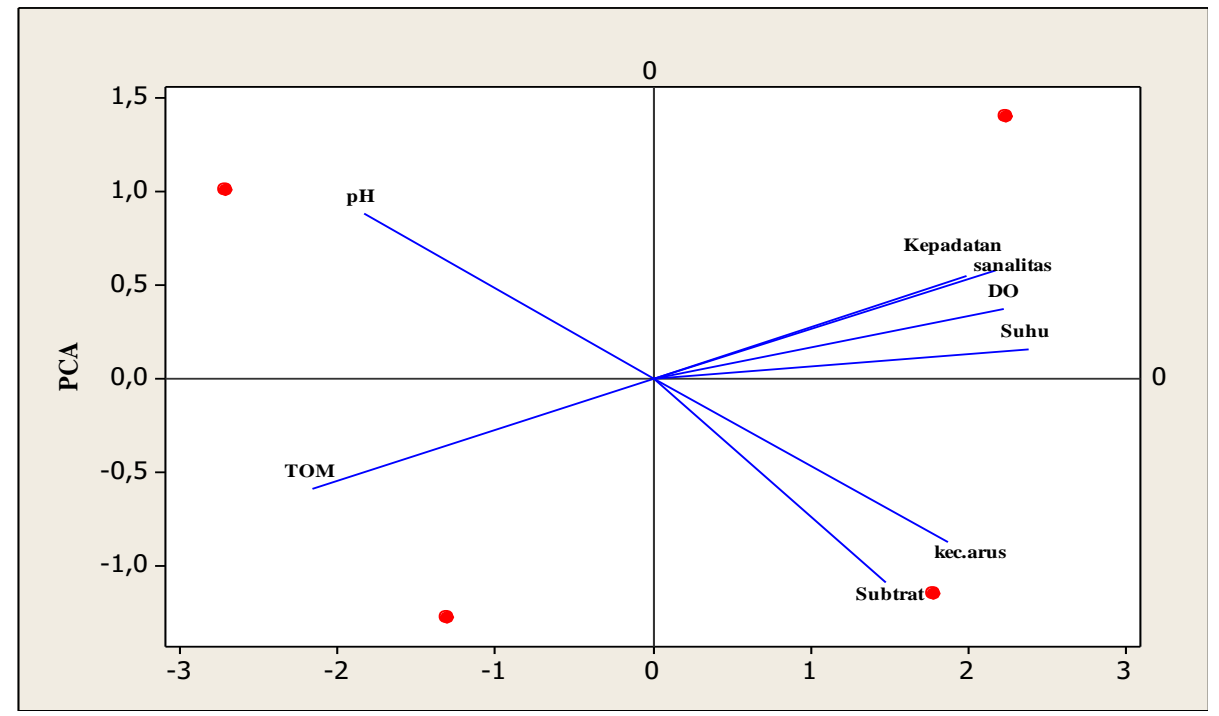

Gambar 4. Hasil Principal Component Analysis

Pada kelompok ketiga Stasiun II ekosistem mangrove dicirikan oleh TOM (total organic metter), TOM yang diukur menggambarkan kandungan bahan organik pada substrat. Kandungan bahan organik pada substrat erat kaitannya dengan penguraian (dekomposisi) serasah. Menurut Tang et al. (2016), proses awal dekomposisi yaitu penghancuran struktur fisik yang sebagian hasilnya akan menjadi detritus yang berukuran kecil. Selanjutnya kelompok keempat Stasiun II ekosistem padang lamun dicirikan oleh kecepatan arus dan substrat. Hubungan kecepatan arus dan substart yaitu kecepatan arus mempengaruhi keberadaan makrozoobentos serta secara tidak langsung mempengaruhi substrat dasar perairan. Menurut Magfirah et al. (2014), arus mempengaruhi transport sedimen dan mengkikis substrat dasar perairan sehingga dapat dibedakan menjadi substrat batu, pasir, liat, ataupun debu.

\section{SIMPULAN}

Pola sebaran Cerithiidae pada seluruh stasiun pengamatan di perairan Pulau Penyengat ditemukan pola persebaran mengelompok. Hasil pola sebaran pada Stasiun I dan II ekosistem padang lamun yang ada aktivitas dan tidak ada aktivitas memiliki nilai yang tidak jauh berbeda yaitu nilai Indeks morista 9,78 dan 8,19, sama halnya pada Stasiun I dan II kawasan mangrove dengan nilai Indeks morista 2,29 dan 2,42.

Hasil jenis Cerithiidae yang dijumpai di perairan Pulau Penyengat sebanyak 6 spesies, dengan kepadatan rata-rata Cerithiidae terdapat pada Stasiun I kawasan ekosistem padang lamun yang ada aktivitas dan tidak ada aktivitas masyarakat memiliki rata-rata yang cenderung sama dengan nilai rata-rata yaitu $25.555 \mathrm{ind} / \mathrm{Ha}$ dan $24.722 \mathrm{ind} / \mathrm{Ha}$. Sama halnya pada Stasiun I dan II kawasan mangrove yang tidak jauh berbeda memiliki nilai rata-rata yang cenderung sama yaitu $20.873 \mathrm{ind} / \mathrm{Ha}$ dan $17.963 \mathrm{ind} / \mathrm{Ha}$.

Berdasarkan hasil principal component analysis, karakteristik penciri lingkungan pada Stasiun I ekosistem mangrove yaitu pH tidak memiliki keterkaitan dengan tingkat kepadatan Cerithiidae. Selanjutnya Pada Stasiun I ekosistem padang lamun terdiri dari Salanitas, suhu, dan DO memiliki keterkaitan terhadap tingkat kepadatan. Pada Stasiun II ekosistem mangrove dengan karakteristik penciri lingkungan yaitu TOM tidak memiliki keterkaitan terhadap tingkat kepadatan. Selanjutnya pada stasiun II ekosistem padang lamun dengan karakteristik penciri lingkungan yaitu Kecepatan arus dan Substrat juga tidak memiliki keterkaitan dengan tingkat kepadatan Cerithiidae.

\section{REFERENSI}

Akhrianti, I., Bengen, Dietriech G., \& Setyobudiandi, I. (2014). Distribusi Spasial dan Preferensi Habitat Bivalvia di Pesisir Perairan Kecamatan Simpang Pesak Kabupaten Belitung Timur. Jurnal Ilmu dan Teknologi Kelautan Tropis, 6(1): 171-185.

Budiasih, R., Supriharyono, \& Muskananfola, R.M. 2015. Analisis Kandungan Bahan Organik, Niterat, Fosfat Pada Sedimen Di Kawasan Mangrove Jenis Rhizophora dan Avicennia Di Desa Timbulsloko, Demak. Diponogoro Journal Of Maquares, 4(3): 66-75.

Delsen, M.S.N., Wattimena. A.Z., \& Saputri, S.D. (2017). Penggunaan Metode Analisis Komponen Utama Untuk Mereduksi Faktor Faktor Inflasi di Kota Ambon. Jurnal Ilmu Matematika dan Terapan, 11(2): 109-118.

Djohar, A.M., Boneka, B.F., Schaduw, W.N.J., Mandagi, V.S., Roeroe, A.K., \& Sumilat, A.D. (2020). Analisis Sampah Laut Dan Kelimpahan Gastropoda Di Ekosistem Mangrove Tongkaina. Sulawesi Utara. Jurnal Ilmiah PLATAX, 8(1) 15-23.

Effendi, H. (2003). Telaah Kualitas Air Bagi Pengelolaan Sumber Daya dan Lingkungan Perairan. Penerbit Kanisisus. Jakarta.

Fachrul, M.F. (2007). Metode Sampling Bioekologi, Bumi Aksara. Jakarta. 
Gohel, S.R., Khushali, M.P., \& Mankodi, C.P. (2016). Population Study of the Family Cerithiidae (Phylum: Mollusca) at Mangrol Coast, Gujarat. India. International Research Journal of Environment Sciences, 5(8), 16-21.

Hatijah, S., Lestari, F., \& Kurniawan, D. (2019). Struktur komunitas gastropoda di Perairan Tanjung Siambang Kelurahan Dompak Kota Tanjungpinang, Provinsi Kepulauan Riau. Jurnal Pengelolaan Perairan, 2(2): 27-38.

Houbrick. S.R. (1985). Genus Clypoemorus Jousseaume. Smithsonian Institution Press. Washington. USA.

Hutagalung, H.P. (1988). Pengaruh Suhu Air Terhadap Kehidupan Organisme Laut. Jurnal Oseana. 13:153-164.

Ira, Rahmadani, \& Irawati, N. (2015). Keanekaragaman dan Kepadatan Gastropoda di Perairan Desa Morindino Kecamatan Kambowa Kabupaten Buton Utara. Jurnal Ilmu Perikanan dan Sumberdaya Perairan, 3(2): 265-272.

Keputusan Menteri Lingkungan Hidup No.51/I/2004. Tentang Pedoman Penetapan Baku Mutu Air Laut. Jakarta.

Lindawaty, Dewiyanti, I., \& Karina, S. (2016). Distribusi dan Kepadatan Kerang Darah (Anadara sp) Berdasarkan Tekstur Substrat di Perairan Ulee Lheue Banda Aceh. Jurnal Ilmiah Mahasiswa Kelautan dan Perikanan Unsyiah, 1(1): 114-123.

Magfirah., Emiyarti., Muh, L.O., \& Haya, Y. (2014). Karakteristik Sedimen Dan Hubungannya Dengan Struktur Komunitas Makrozoobentos Di Sungai Tahi Ite Kecamatan Rarowatu Kabupaten Bombana Sulawesi Tenggara. Jurnal Mina Laut Indonesia, 04(14): 117-131.

Minarni, Jahidin, \& Darlian, L. (2016). Kelimpahan Gastropoda Pada Habitat Lamun Di Perairan Desa Tongali Kecamatan Siompu. Jurnal AMPIBI, 1(2): 17-21.

Normalasari, Melani, W.R., \& Apriadi, T. (2019). Struktur Komunitas Gastropoda Di Perairan Air Kelubi Desa Resun Pesisir Kecamatan Lingga Utara Kabupaten Lingga. Jurnal Akuatiklestari, 2(2), 10-19. https://doi.org/10.31629/akuatiklestari.v2i2.993

Ode, I. (2017). Kepadatan dan Pola Distribusi Kerang Kima (Tridacnidae) di Perairan Teluk Nitanghahai Desa Morella Maluku Tengah. Jurnal Agribisnis Perikanan, 10(2): 1-6.

Odum, E. (1996). Dadar-dasar Ekologi. Edisi Ketiga, di terjemahkan oleh T.Samingan. Universitas Gajah Mada. Yogyakarta.

Piranto, D., Riyantini, I.M., Kurnia, U.A., \& Prihadi, J.D. (2019). Karakteristik Sedimen Dan Pengaruhnya Terhadap Kelimpahan Gastropoda Pada Ekosistem Mangrove Di Pulau Pramuka. Jurnal Perikanan dan Kelautan, 9(1): 20-28.

Putra, S., Ali, S.M., \& Huda, I. (2018). Pola sebaran Gastropoda Di Ekosistem Mangrove Sungai Reuleung Leupung Kabupaten Aceh Besar. Jurnal Biotik, 6(1): 59-62.

Rangan, J.K. (2010). Inventory Gastropoda in the Floor of Mangrove Forest Rap Rap Village South Minahasa Regency of North Sulawesi. Jurnal Perikanan dan Kelautan, VI(1): 63-66.

Ridwan, M., Fathoni, R., Fatihah, I., \& Pangestu, D.A. (2016). Struktur Komunitas Makrozoobenthos Di Empat Muara Sungai Cagar Alam Pulau Dua, Serang, Banten. Al-Kauniyah Jurnal Biologi, 9(1): 57-65.

Riniatsih, I. (2015). Distribusi Muatan Padatan Tersuspensi (MPT) di Padang Lamun di Perairan Teluk Awur dan Pantai Prawean Jepara. Jurnal Kelautan Tropis. 18(3):121-126.

Rosdatina, Y., Apriadi, T., \& Melani, W.R. (2019). Makrozoobentos Sebagai Bioindikator Kualitas Perairan Pulau Penyengat. Kepulauan Riau. Jurnal Pengelolaan Lingkungan Berkelanjutan Journal of Environmental Sustainability Management, 3(2):309-317.

Saputri, D. (2019). Pola Sebaran Dan Kepadatan Cerithiidae di Perairan Kampe Desa Malang Rapat Kecamatan Gunung Kijang Kabupaten Bintan, [Skripsi]. Universitas Maritm Raja Ali Haji. Kepulauan Riau.

Sianu, N.E., Sahami, F.M., \& Kasim, F. (2014). Keanekaragaman dan Asosiasi Gastropoda dengan Ekosistem Lamun di Perairan Teluk Tomini. Jurnal Ilmiah Perikanan dan Kelautan, 2(4): 156-163.

Supratman, O., Farhaby, M.A., \& Ferizel, J. (2018). Kelimpahan Dan Keanekaragaman Gastropoda Pada Zona Intertidal Di Pulau Bangka Bagian Timur. Jurnal Enggano, 3(1): 10-21.

Tang, M., Nur, A.I., \& Ramli, M. (2016). Studi Kondisi Ekosistem Mangrove dan Produksi Detritus di Pesisir Kelurahan Lalowaru Kecamatan Moramo Utara Kabupaten Konawe Selatan. Jurnal Manajemen Sumber Daya Perairan, 1(4): 439-450.

Wahyuni, S., Yolanda, R., \& Purnama, A.A. (2014). Struktur Komunitas Gastropoda (Molusca) Di Perairan Bendungan Menaming Kabupaten Rokan Hulu Riau. [Tesis]. Program Studi Pendidikan Biologi. Fakultas Keguruan Dan Ilmu Pendidikan. Universitas Pasir Pengaraian.

Yuniarti, N. (2012). Keanekaragaman dan Distribusi Bivalvia dan Gastropoda (Moluska) di Pesisir Glayem Juntinyuat, Indramayu, Jawa Barat. [Skripsi]. Departemen Biologi Fakultas Matematika Dan Ilmu Pengetahuan Alam. Institut Pertanian Bogor. Bogor 